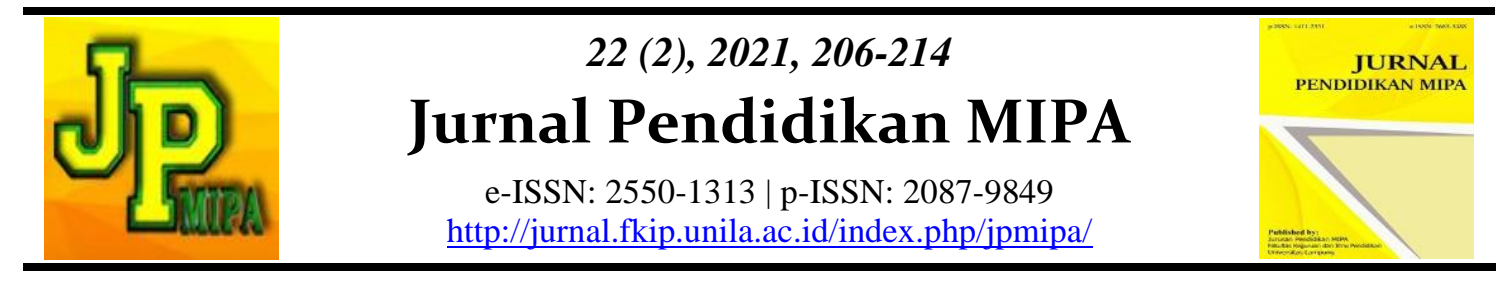

\title{
Sustainability Literacy of Student's Junior High School at Science Learning in Schools
}

\author{
Wahyuni Adam*, Anna Permanasari, Ida Hamidah
}

Departement of Science Education, Universitas Pendidikan Indonesia

\begin{abstract}
This article aims to see whether science learning contributes to the sustainable literacy of junior high school students in school. The method used in this research is the preexperimental method. The instrument used is 15 multiple choice questions. The sample used in this study was 32 students of class IX SMP Negeri 3 Watampone. The overall N-Gain score is 0.29 in the low category. While Ngain in terms of economic aspects 0,4 is in the medium category, the social aspect 0,3 is in the medium category, and the environment 0,2 is in the low category. The percentage of sustainability literacy from the Economic aspect is $67.5 \%$ in the medium category, $65 \%$ in the social aspect in the medium category, and the environmental aspect $55.63 \%$ in the medium category. Thus, this study can be concluded that science learning contributes to the sustainability literacy of students in the low category.
\end{abstract}

Keywords: sustainabily literacy, education for sustainable development, science learning.

Abstrak: Artikel ini bertujuan untuk melihat apakah pembelajaran IPA berkontribusi dalam literasi keberlanjutan siswa SMP di sekolah. Metode yang digunakan dalam penelitian ini adalah metode pra-ekperimen. Instrumen yang digunakan berupa 15 soal pilihan ganda. Sampel yang digunakan dalam penelitian ini sebanyak 32 siswa siswa kelas IX di SMP Negeri 3 Watampone. Hal ini ditunjukkan dengan Perolehan skor N-Gain secara keseluruhan 0,29 kategori rendah. Sedangkan Ngain ditinjau dari aspek ekonomi 0,4 kategori sedang, aspek sosial 0,3 kategori sedang, dan lingkungan 0,2 kategori rendah. Presentase literasi keberlanjutan dari aspek Ekonomi 67,5\% kategori sedang, aspek sosial 65\% kategori sedang, aspek lingkungan 55,63\% kategori sedang. Dengan demikian, penelitian ini dapat disimpulkan bahwa pembelajaran ipa berkontribusi dalam keberlanjutan literasi siswa dengan kategori rendah.

Kata Kunci: literasi keberlanjutan, education for sustainable development, pembelajaran IPA.

\section{INTRODUCTION}

Education for Sustainable Development (ESD) is a concept that education need today. ESD is a concept with a very broad scope which includes aspects of education. ESD also covers several aspects of education, including planning, program implementation, curriculum, finance, assessment, administration, policy development and learning. ESD is a strong interaction between various fields, namely education, paradigms, and public awareness with the aim of realizing a quality and sustainable future (UNESCO, 2012).

According to Muhson, (2010) said that ESD is an education that is guided by the pillars of sustainable development, all of which are interrelated, society, environment, economy and culture whose ultimate goal is to form quality education. ESD is an educational approach that is packaged by incorporating sustainable values to create the desired quality of education that good and sustainable education that can be used in the future or in the future. Global sustainable development targets are formulated in an

Wahyuni Adam et al.

Email: wahyuniadam94@gmail.com
DOI: http://dx.doi.org/10.23960/jpmipa/v22i2.pp206-214

Received: 16 October 2021

Accepted: 15 December 2021 
agreement of 193 countries called Sustainable Development Goals (SDGs) or Global Goals (Pedersen, 2018).

The Sustainable Development Goals (SDGs) are part of the 2030 agenda for sustainable development which was declared in 2015 by the United Nations. This agenda is expected to influence various government and donor financial policies and priorities that can be used to support the achievement of the Sustainable Development Goals (IPPF) goals. This sustainable development agenda that known as the Sustainable Development Goals (SDGs). Morton et al. (2017) said that the SDGs are a global agenda to create justice and sustainable health from the planet to social life. The SDGs consist of 17 main objectives with measurable achievement indicators focused on three aspects, environmental, social, and economic.

Mensah (2019) states that the concept of Sustainable Development Goals (SDGs) is intended to address the root causes of poverty, overshadowing the discussion of the nonexistent scope of areas such as hunger, education, health, gender, water and sanitation, economic growth, innovation, energy, population growth, infrastructure, sustainability of cities and communities, consumption and production, industry, natural resources, climate change, and peace and justice. Based on the sustainable development goals in the SDGs, it can be concluded that the SDGs target sustainable development in environmental, social, and economic matters. Sustainable development is intended to achieve progress from various aspects, social, economic growth, and creating peace (García-Feijoo, Eizaguirre, \& Rica-Aspiunza, 2020).

Segera (2015) said that by introducing ESD and instilling ESD values to students in schools, it is hoped that students will be able to understand and apply the values of sustainable development to maintain the sustainability of life in a safe and comfortable future. According to Dube \& Lubben (2011) the international community looks forward that Education for Sustainable Development (ESD) is intended to address global problems that are very common today such as environmental degradation, poverty, and health. Therefore, Berglund et al. (2020) said that Sustainable Development is one of the biggest challenges faced by humans today where we have to create a sustainable environment and at the same time also be able to develop socio-economic life.

Building a more sustainable self, community, society, and world according to Stibbe (2009) requires more than just sustainable knowledge, but requires sustainability literacy which refers to the skills, attitudes, competencies, dispositions, and values needed to survive and thrive. thrive in a world that continues to decline in a way that minimizes that decline as far as possible. Gatti et al. (2018) states that Education for Sustainable Development does not only affect the content of education but also on the implementation of the process and its results. This causes new changes in culture, learning processes and techniques in learning. So, it is the same as what Indrati \& Hariadi (2016) said that all education stakeholders should think together about sustainable education which is considered important for life in the future. So it is hoped that it can be implemented in schools throughout Indonesia through science subjects.

The focus of education in the 21 st century is experiencing a shift, that is with the demand to have competence in thinking skills and sustainability literacy. The background of the declining quality of the environment which is classified as bad makes every individual need education related to sustainable development. One of the efforts to achieve environmental sustainability is the role of universities as a vehicle for preventing ecological or environmental damage. Ecological prevention efforts in universities, one of which is the development of sustainability literacy which is one 
aspect or dominant that must be in the curriculum at universities (Diamond \& Irwin, 2013).

According to Thomas (2009) states that in various universities, sustainable development education has been very much introduced. These efforts toward to create a sustainable student mindset. In fact, to form sustainable literacy skills, the thing that must be explored and honed first is how students are able to examine a problem that exists in the surrounding environment well, be it in the economic, social, and environmental fields.

The initial level of sustainability literacy taken through Difficultest is still at a medium level. Therefore, there is a need for improvement so that the level of sustainability literacy can be at a high level. In Coronado-Marín et al.(2020) said the results were inadequate, the SDGs on Health and Welfare and Clean Water and Sanitation. So there is a need for further improvement on these two points. The level of ESD literacy is closely related to how students are trained/trained in classroom learning which states that ESD literacy can be improved through learning by using extension, training, and simulation methods as well as stating that a student can be said to have sustainable literacy when he combines understanding about the need for change with appropriate knowledge and skills, and to be able to recognize and appreciate continuing action in others.

The description above indicates that learning that has characteristics such as going directly to the field, carrying out sustainable practices has the potential to build students' ESD literacy that we can build from an early age. Based on the Sustainability Literacy Test which conducted by Sulitest in 57 countries, the results are that students, faculty, and staff of higher education institutions get an average score of 55\% for sustainability literacy. They understand more about human rights and economic trends and less about principles related to the environment. Based on previous research, it was found that students' sustainable literacy skills were still medium categorized for sustainability. As stated by Kieu et al. (2016) that at a very early stage the level of sustainability literacy is still medium. Therefore, to look at the ESD Literacy of junior high school students, the formulation of the problem in this research is about "How Science Learning Contributes to the Sustainability Literacy (ESD) of students in Economic, Social, and Environmental Aspects".

\section{METHOD}

This research uses a pre-experimental method with research design used is one group pretest-posttest design. The population in the study was all 9th grade students in one of the junior high schools in Watampone of South Sulawesi at SMPN 3 Watampone district of Watampone. The sample used in this study as many as 32 students from grade $9^{\text {th }}$ with sampling techniques, namely purposive sampling. Purposive sampling is a sampling technique based on knowledge of population characteristics and the purpose of research (Fraenkel, J. R., Wallen, N. E., \& Hyun, 2012). Data collection techniques using instruments in the form of multiple-choice questions as many as 15 questions adapted in questions that have been previously tested which aim to measure sustainability literacy. The questions consist of three aspects of sustainability literacy, namely economic, social, and environmental aspects. Each aspect consists of five questions, each of which represents a sub-indicator of sustainability literacy. In this study, out of 30 sustainability literacy sub-indicators used only 15 sub-indicators. The indicators can be seen in Table 1 . 
Table 1. Aspects and Sub. Indicators Measured (Décamps, Barbat, Carteron, Hands, \& Parkes, 2017)

\begin{tabular}{|c|c|}
\hline Aspect & Sub. Indicator \\
\hline \multirow{5}{*}{ Economy } & $\begin{array}{l}\text { 1. Local and global economic systems; paradigm; positive results with } \\
\text { negative impacts; law; how an organization works; land use; gender } \\
\text { equality; etc }\end{array}$ \\
\hline & $\begin{array}{l}\text { 2. Capacity for empathy, compassion, solidarity; future-oriented and } \\
\text { strategic thinking }\end{array}$ \\
\hline & $\begin{array}{l}\text { 3. Networks; communication skills; build effective coalitions for systemic } \\
\text { change }\end{array}$ \\
\hline & 4. Respect and care for the community of life, now and in the future \\
\hline & 5. The Golden Rule (treat others the way you would want them to treat you) \\
\hline \multirow{5}{*}{ Social } & $\begin{array}{l}\text { 6. Social Perspective: where are we (demography, (inequality), gender } \\
\text { equality, education ...) and why sustainability is both an urgency and an } \\
\text { opportunity }\end{array}$ \\
\hline & $\begin{array}{l}\text { 7. Social and governance structures in global and local governance; } \\
\text { paradigm; positive results with negative impacts ; law; how an organization } \\
\text { works; land use; gender equality; etc }\end{array}$ \\
\hline & $\begin{array}{l}\text { 8. In local and global social and governance structures, focusing on: } \\
\text { education and culture }\end{array}$ \\
\hline & $\begin{array}{l}\text { 9. Examples and ideas to learn from: case studies of success or failure; } \\
\text { technological, strategic, or social innovation }\end{array}$ \\
\hline & $\begin{array}{l}\text { 10. How does one act efficiently to create individual and system change? (a } \\
\text { person can be an individual, an organization, etc.) }\end{array}$ \\
\hline \multirow{5}{*}{$\begin{array}{c}\text { Environ } \\
\text { mental }\end{array}$} & $\begin{array}{l}\text { 11. Ecological Perspective: where we are, and why sustainability is both an } \\
\text { urgency and an opportunity }\end{array}$ \\
\hline & 12. How to initiate, maintain and accelerate system changes \\
\hline & $\begin{array}{l}\text { 13. Concepts, Tools, Frameworks, more from NGOs or smaller networks } \\
\text { (Like cradle to cradle, Natural Capitalism, The Natural Step, Ecological } \\
\text { Footprint, etc) }\end{array}$ \\
\hline & $\begin{array}{l}\text { 14. How can one realize its role and impact? (a person can be an individual, } \\
\text { an organization, etc.) }\end{array}$ \\
\hline & 15. Holistic versus mechanistic worldview \\
\hline
\end{tabular}

The analysis technique of student sustainability literacy is based on increasing scores in each aspect of sustainability literacy on the pretest and posttest using the $\mathrm{N}$ Gain score. Student sustainability literacy analysis techniques based on improving sustainability literacy indicator scores on pretest and posttest use N-Gain scores and are interpreted with categories when $\mathrm{g} \geq 0,7$ classified high, $0,3 \leq \mathrm{g}<0,7$ classified medium, and $\mathrm{g}<0,3$ classified low (Hake, 1999).

This study consisted of four meetings that lasted for 2 weeks. The first meeting, students were given a pretest to test their initial abilities regarding sustainability literacy. The second meeting, students were given the task of observing the surrounding environment regarding what types of waste were in the trash around them, observing the sea or rivers in the surrounding environment and giving the task of processing plastic waste into something of economic value without spending a lot of money. The third meeting, the processed plastic waste that has been made and then presented in front of the class by explaining what materials and tools are used, the dangers of using plastic in everyday life, the impact of the next 50 years if plastic continues to be produced and more and more, behavior humans that harm nature and the impacts caused and how to overcome them. The fourth meeting, giving a posttest to see if after learning science about sustainability can improve students' sustainability literacy. 


\section{RESULT AND DISCUSSION}

The results of this study aim to determine the contribution of science learning in Sustainability literacy which can be seen through the results of the pretest and posttest. Multiple choice questions on sustainability literacy questions as many as 15 numbers are given before and after learning with the time provided for about 30 minutes. The results of the students' pretest and posttest can be seen in the graph below.

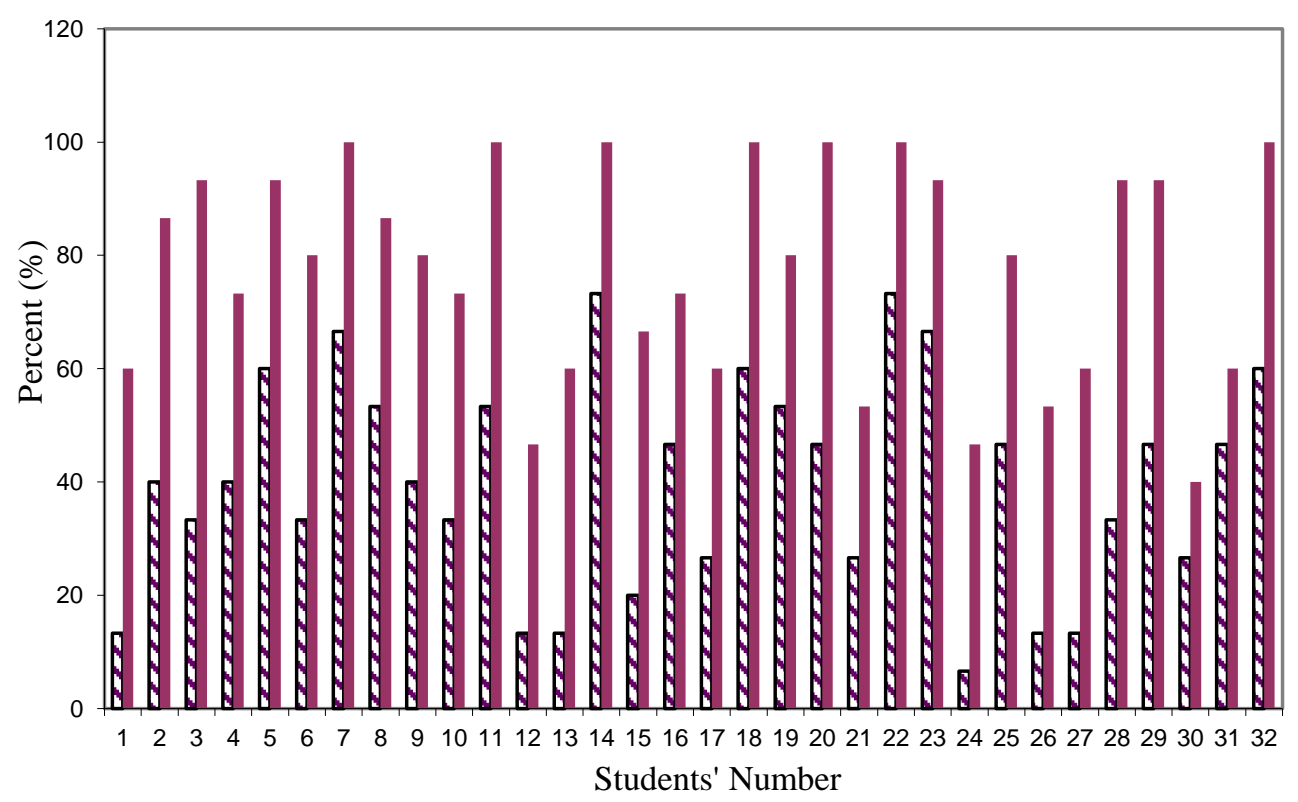

Figure 1. Graph of Student Sustainability Literacy Pretest and Posttest

Figure 1 shows the increase in the students' sustainability literacy scores on the pretest and posttest. Figures 1-32 in Figure 1 show students who took the pretest and posttest. While the numbers $0-15$ indicate the percentage of pretest and posttest scores obtained by students. The minimum score in this test is 0 and the maximum score is 15 . In this Sustainability Literacy test, no student has succeeded in achieving the maximum score. The highest pretest score obtained was 11 and the smallest pretest score was 1 . Meanwhile, the highest posttest score obtained was 13 and the smallest posttest score was 5. Prior to the N-gain calculation, the data from the Sustainability Literacy results were analyzed using SPSS 16 and Microsoft Excel.

Based on the graph in Figure 1, it can be seen that there was a significant increase after learning was given, this was indicated by more than $50 \%$ of students getting a higher score than the score before learning was given. The increase in the average score of students is 2-3 from before this is because in the learning process phenomena are inserted in the surrounding environment and discuss what causes this to happen to provide the right solution in order to prevent or minimize such incidents from happening again in the environment around us at the same time. future. As said Segera, (2015) that by introducing ESD and instilling ESD values to students in schools, students are expected to be able to understand and apply the values of sustainable development to maintain a safe and comfortable future. There are also students who do not experience an increase in scores and there are even two students who experience a 
decrease in scores after learning. This is because after learning the student's perception is still the same as before the lesson so that there is no increase or even a decrease in score. However, when viewed as a whole, the increase in student scores in learning is considered positive to support sustainability literacy.

Based on the values obtained from the results of the normality test using ShapiroWilk, it was stated that the pretest data were normally distributed and the posttest data were normally distributed. In this study, three aspects of sustainability literacy were measured, namely economic, social, and environmental aspects Décamps et al., 2017). In these three aspects, each aspect gets a different percentage. The percentage of each aspect can be seen in Table 2.

Table 2. Sustainability Literacy Percentage in Every Aspect

\begin{tabular}{ccl}
\hline Aspect & Percentage $(\%)$ & Category \\
\hline Economic & 67.5 & Medium \\
\hline Social & 65 & Medium \\
\hline Environment & 55.63 & Medium \\
\hline
\end{tabular}

Table 2 shows the percentage on the Economic, Social, and Environmental aspects. The aspect that received the highest percentage was from the Economic aspect with a percentage of $67.5 \%$ included in the medium category. The social aspect is in the medium category with a percentage of $65 \%$ and the environmental aspect is in the medium category with a percentage of $55.63 \%$.

The economic aspect obtained the highest percentage of the three aspects measured, namely $67.5 \%$. This can be seen from the awareness of students who are aware of the importance of processing waste, especially plastic waste into items that can be of high selling value, for example, processed plastic bottles into flower vases, piggy banks, pencil cases that are processed in such a way that they become beautiful and unique and can be used in long term and economical value.

Next from the social aspect with a percentage of $65 \%$, it reflects that students have started working together to protect their environment by inviting them to do mutual cooperation around the school environment by separating plastic and non-plastic waste, socializing with peers about the importance of maintaining cleanliness. environment and reduce the use of plastic and the future impact if not reduce the use of plastic from now on.

The third aspect is the environmental aspect with a percentage of $55.63 \%$ which is smaller than the two previous aspects. This is because there are still a number of students who still do not agree with the transition of plastic bags into shopping bags that can be used repeatedly so that there are still many students who do not know the dangers and impacts of using plastic in everyday life that can damage the environment. in terms of all aspects of sustainability literacy is still in the medium category. In line with (Décamps, 2017) which explains that the two main contributions in the most difficult application are mapping the extent of sustainability literacy skills in the world and monitoring their development over time. 
3.

\begin{tabular}{ccccc}
\hline Economic & 78 & 108 & 0.4 & Medium \\
\hline Social & 75 & 104 & 0,3 & Medium \\
\hline Environment & 72 & 89 & 0,2 & Low \\
\hline
\end{tabular}

Table

Sustainability literacy n-gain in every aspect

Each aspect of sustainability literacy is visible that of the three aspects measured the highest increase is obtained from the economic aspect with Ngain of 0.4 which is included in the medium category. Based on the Ngain value obtained, it shows an increase in sustainability literacy in students. Learning by processing plastic waste into something of economic value can increase students' sustainability literacy, making flower vases, pencil cases, piggy banks, and plastic dolls to increase students' awareness of being able to process waste into something that can be used and is worth selling and not just thrown away.

In line with research conducted by Kristianto (2020) which states that organic waste management with student assistance in the manufacture of environmentally friendly recycled products aims to develop a sustainable student mindset. Organic waste management can also improve students' skills in something creative (Dale \& Newman, 2005)also support to realize the community's economy. So the poverty rate will decrease. In addition to organic waste, waste management by recycling studio or studio waste for reuse is useful for realizing a sustainable lifestyle, this fully supports sustainability literacy skills, namely skills in reducing environmental impacts on us.

The second aspect is the social aspect with a Ngain gain of 0.3 which is included in the medium category. Based on the Ngain value obtained, it shows an increase in sustainability literacy in students, although it is not large. This is shown in questions that are included in the social aspect, there are still many students who answer incorrectly. This is due to the perception of students that they are still not optimal in terms of social sustainability.

Aspect is the environmental aspect with a Ngain of 0.2 which is included in the low category. Based on the Ngain value obtained, it shows a slight increase in sustainability literacy in students this is because there are still many students who are reluctant to switch from plastic in everyday life because knowledge of plastic is still minimal so that many do not know if plastic is used continuously then the earth will The next 50 years will be polluted with plastic waste. According to Kieu et al. (2016) they understand more about social life and economic trends and less about principles related to the environment. Based on previous research, it was found that students' sustainable literacy skills were still in the moderate category for sustainability.

\section{CONCLUSION}

Based on the data analysis and discussion, it can be concluded that in this study, science learning made a small contribution to sustainability literacy, this was indicated by the Ngain score where in every aspect measured from the pretest and posttest scores an increase. Ngain as a whole is 0.29 low category, while if viewed from Ngain every aspect is economic aspect 0.4 moderate category, social aspect is 0.3 medium category 
and environmental aspect is 0.2 low category. Likewise, from the three aspects of sustainability, economic aspects, social aspects, and environmental aspects, the percentages are $67.5 \%, 65 \%$, and $55.63 \%$, respectively.

\section{REFERENCES}

Berglund, T., Gericke, N., Boeve-de Pauw, J., Olsson, D., \& Chang, T. C. (2020). A cross-cultural comparative study of sustainability consciousness between students in Taiwan and Sweden. Environment, Development and Sustainability, 22(7), 6287-6313. https://doi.org/10.1007/s10668-019-00478-2

Coronado-Marín, A., Bautista-Cerro, M. J., \& Murga-Menoyo, M. A. (2020). Business , Trade and Institutional Sustainability. In International Business, Trade and Institutional Sustainability (pp. 1021-1041). Springer.

Dale, A., \& Newman, L. (2005). Sustainable development, education and literacy. 6(4), 351-362. https://doi.org/10.1108/14676370510623847

Décamps, A., Barbat, G., Carteron, J. C., Hands, V., \& Parkes, C. (2017). Sulitest: A collaborative initiative to support and assess sustainability literacy in higher education. International Journal of Management Education, 15(2), 138-152. https://doi.org/10.1016/j.ijme.2017.02.006

Diamond, S., \& Irwin, B. (2013). Using e-learning for student sustainability literacy: Framework and review. International Journal of Sustainability in Higher Education, 14(4), 338-348.

Dube, T., \& Lubben, F. (2011). Swazi teachers' views on the use of cultural knowledge for integrating education for sustainable development into science teaching. African Journal of Research in Mathematics, Science and Technology Education, 15(3), 68-83. https://doi.org/10.1080/10288457.2011.10740719

Fraenkel, J. R., Wallen, N. E., \& Hyun, H. H. (2012). How To Design And Evaluate Research In Education. New York-Mcgraw-Hill.

García-Feijoo, M., Eizaguirre, A., \& Rica-Aspiunza, A. (2020). Systematic review of sustainable-development-goal deployment in business schools. Sustainability (Switzerland), 12(1), 1-19.

Gatti, L., Ulrich, M., \& Seele, P. (2018). Education for sustainable development through business simulation games: An exploratory study of sustainability gamification and its effects on students learning outcomes. Journal of Cleaner Production.

Hake, R. R. (1999). Analyzing change/gain score. Retrieved 25 November, 2021 from http://www.physics.indiana.edu/nsdi/AnalyzingChange-Gain.pdf

Indrati, D. A., \& Hariadi, P. P. (2016). Esd ( Education for Sustainable Development ) Melalui Pembelajaran Biologi. Symposium on Biology Education, 371-382.

Kieu, T. K., Fernandez, G., \& Shaw, R. (2016). Usefulness of a Sustainability Literacy Test. 265-277. https://doi.org/10.1007/978-4-431-55078-5_17

Kristianto, A. (2020). Pendampingan dan Pelatihan Pengelolaan Limbah Organik Menjadi Produk Bernilai Ekonomi di SMA Negeri 1 Bengkayang [Mentoring and Training in Organic Waste Management Becomes An Economic Value Product at Sma Negeri 1 Bengkayang]. Jurnal Abdimas BSI: Jurnal Pengabdian Kepada Masyarakat, 3(2), 190-197. https://doi.org/10.31294/jabdimas.v3i2.8093

Mensah, J. (2019). Sustainable development: Meaning, history, principles, pillars, and implications for human action: Literature review. Cogent Social Sciences, 5(1), 121.

Morton, S., Pencheon, D., \& Squires, N. (2017). Sustainable Development Goals 
(SDGs), and their implementation. British Medical Bulletin, 124(1), 81-90.

Muhson, A. (2010). Pengembangan Media Pembelajaran Berbasis Teknologi Informasi. Jurnal Pendidikan Akuntansi Indonesia, 8(2). https://doi.org/10.21831/jpai.v8i2. 949

Pedersen, C. S. (2018). The Sustainable Development Goals (SDGs) are a Great Gift to Business. Procedia Cirp, 69(May), 21-24.

Segera, N. B. (2015). Education for Sustainable Development (ESD) Sebuah Upaya Mewujudkan Kelestarian Lingkungan [Education for Sustainable Development (ESD) an Effort to Realize Environmental Sustainability]. SOSIO DIDAKTIKA: Social Science Education Journal, 2(1), 22-30. https://doi.org/10.15408/sd.v2i1. 1349

Stibbe, A. E. (2009). The handbook of sustainability literacy: Skills for a changing world. Green Books.

Thomas, I. (2009). Critical thinking, transformative learning, sustainable education, and problem-based learning in universities. Journal of Transformative Education, 7(3), 245-264. https://doi.org/10.1177/1541344610385753

UNESCO. (2012). Education For Sustainable Development. United Nations Educational, Scientific And Cultural Organization. Paris, France. 